\title{
The Utilization of Propionate by Micrococcus denitrificans
}

\author{
By JANET SMITH AND H. L. KORNBERG \\ Department of Biochemistry, University of Leicester, Leicester
}

(Accepted for publication 28 November 1966)

\section{SUMMARY}

Suspensions of Micrococcus denitrificans, growing with propionate as sole carbon source, incorporated ${ }^{14} \mathrm{C}$ from $\left[1-{ }^{14} \mathrm{C}\right]$ propionate or from sodium $\left[{ }^{14} \mathrm{C}\right]$ bicarbonate, initially into succinate and then into intermediates of the tricarboxylic acid cycle and amino acids derived therefrom. In the presence of $4 \mathrm{~mm}$-sodium arsenite, the oxidation of propionate and of L-malate by washed organisms proceeded only to the level of pyruvate, which accumulated: when sodium $\left[{ }^{14} \mathrm{C}\right]$ bicarbonate was also present, the pyruvate formed from propionate, but not that formed from L-malate, was highly radioactive. Cell-free extracts of propionate-grown $M$. denitrificans catalysed the formation of labelled methylmalonyl-coenzyme A, succinyl-coenzyme A and succinate from sodium $\left[{ }^{14} \mathrm{C}\right]$ carbonate $+\mathrm{ATP}+$ either propionate and coenzyme A, or propionyl-coenzyme A. The evidence thus obtained indicates that propionate enters the tricarboxylic acid cycle of $M$. denitrificans, preponderantly via activation to propionyl-coenzyme $\mathrm{A}$, followed by carboxylation to methyl-malonyl coenzyme $\mathrm{A}$, isomerization to succinyl-coenzyme $\mathrm{A}$ and hydrolysis to succinate.

\section{INTRODUCTION}

Micrococcus denitrificans is unusual among micro-organisms in that, during growth on acetate, the glyoxylate cycle appears not to be the major route for the maintenance of a functioning tricarboxylic acid cycle (French, Kornberg \& Morris, 1964) and, during growth on glycollate or other precursors of glyoxylate, this purpose is achieved via an apparently unique pathway involving the formation and cleavage of erythro- $\beta$-hydroxyaspartate (Kornberg \& Morris, 1965). Since it is known that micro-organisms utilize propionate by a variety of different routes (for brief survey, see Callely \& Lloyd, 1964), it was of interest to determine whether the utilization of this $\mathrm{C}_{3}$-acid by $M$. denitrificans manifested unusual features similar to those exhibited by this organism in its utilization of $\mathrm{C}_{2}$-acids. The results obtained show that propionate is utilized by a pathway similar to that operating in mammalian systems but which has been observed only rarely to occur in bacteria.

\section{METHODS}

Organisms used. The strain of Micrococcus denitrificans, obtained from Dr June Lascelles, had been originally supplied by Dr W. Verhoeven.

Growth of the organism. Cultures of Micrococcus denitrificans were maintained and grown as described by Kornberg \& Morris (1965) except that sodium propionate was substituted for sodium glycollate in all media.

Other experimental procedures. The measurement of the growth of Micrococcus 
denitrificans, the incorporation of isotope from $\left[{ }^{14} \mathrm{C}\right]$-labelled substrates by growing cultures, the assay and identification of labelled compounds, the preparation of cell-free extracts and the determination of protein were performed as previously described (Kornberg \& Morris, 1965). Propionyl-coenzyme A was prepared from propionic acid anhydride and coenzyme A (Stadtman, 1957).

Chemicals used. Radioactive materials were obtained from the Radiochemical Centre, Amersham, Buckinghamshire. Coenzyme A, ATP, $\alpha$-oxoacids and tris were purchased from the Boehringer Corporation (London) Ltd.; L-malic acid from Koch-Light Laboratories Ltd., Colnbrook, Bucks., and all other materials from British Drug Houses Ltd., Poole, Dorset.

\section{RESULTS}

Incorporation of $\left[1-^{14} \mathrm{C}\right]$ propionate by whole organisms

When sodium $\left[1-{ }^{14} \mathrm{C}\right]$ propionate was added to a suspension of Micrococcus denitrificans, which had been grown in a medium containing propionate as sole carbon source and which had been resuspended in fresh propionate medium, isotope was rapidly incorporated into cellular components. Samples, taken from $10 \mathrm{sec}$. to $3 \mathrm{~min}$. after addition of the labelled material, were received into hot ethanol and were analysed by two-dimensional paper chromatography and autoradiography (Kornberg 1958). Such samples showed the incorporated ${ }^{14} \mathrm{C}$ to be distributed mainly between the tricarboxylic acid cycle intermediates citrate, malate, fumarate and succinate, and the amino acids derived directly from the cycle, aspartate and glutamate (Fig. 1). It was apparent that, after 1.5-2 min., most of the labelled material in any sample was present as malate and glutamate, with the other $\mathrm{C}_{4}$-acids and citrate each contributing less than $10 \%$ to the total radioactivity of the sample; these relative amounts of radioactive substances presumably reflected also the relative amounts of the various intermediates present in the ethanol-soluble 'pools' in the bacteria. However, it was also clear that the distribution of isotope amongst these substances at earlier times was not in accordance with the distribution observed after the isotopic steady state condition had been reached. Initially, over $45 \%$ of the total ${ }^{14} \mathrm{C}$ incorporated was present in succinate, and the proportion of labelled succinate in the samples decreased with time, whilst the proportions of other labelled materials remained constant or increased. This showed that succinate was the earliest stable material formed from [1-14 $\mathrm{C}]$ propionate in the intact organisms, and indicated that propionate was utilized via its carboxylation.

\section{Incorporation of ${ }^{14} \mathrm{CO}_{2}$ by whole organisms}

A consequence of this inference would be that the pattern of isotope incorporation observed when sodium $\left[{ }^{[4} \mathrm{C}\right]$ bicarbonate is added to Micrococcus denitrificans suspended in propionate growth medium must be closely similar to that observed when [1-14 C]propionate is the labelled material. As shown by the results in Fig. 2 this proved to be the case. Glutamate and malate again contained most of the incorporated ${ }^{14} \mathrm{C}$ after $1.5-2 \mathrm{~min}$., with aspartate and succinate contributing less than $15 \%$ each (citrate, which contained less than $5 \%$ has been omitted from Fig. 2), and this distribution differed markedly from that observed with samples taken at earlier times. Initially, succinate contained a much higher proportion of ${ }^{14} \mathrm{C}$ than did any 
other component of the ethanol-soluble fraction. The rapid decrease with time in the proportion of labelled succinate present in the samples suggested that the other isotopically labelled materials were derived from labelled succinate, which was thus the main port of entry of isotope from $\left[{ }^{14} \mathrm{C}\right]$ bicarbonate. Since, during growth on substances other than propionate, $M$. denitrificans incorporates isotope from $\left[{ }^{14} \mathrm{C}\right]$ bicarbonate initially into malate and not into succinate (H. L. Kornberg \& J. Smith, unpublished observations), this finding supports the view that the utilization of propionate by these organisms necessarily involves its carboxylation to succinate.

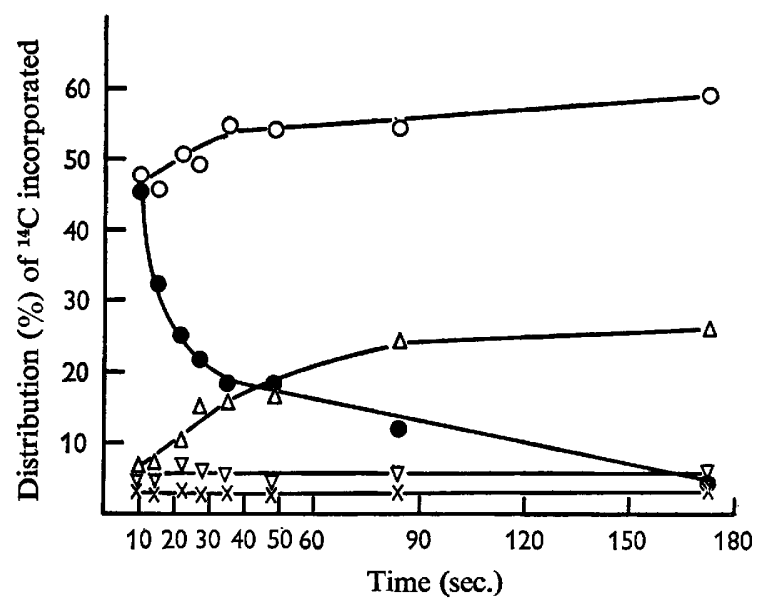

Fig. 1

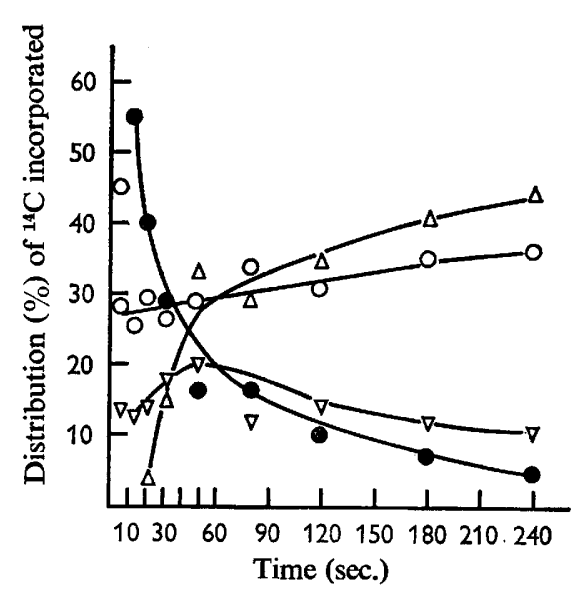

Fig. 2

Fig. 1. Distribution (\%) of isotope incorporated from $\left[1-{ }^{14} \mathrm{C}\right]$ propionate by propionategrown Micrococcus denitrificans into malate $(O)$, succinate $(O)$, citrate $(\times)$, glutamate $(\triangle)$ and aspartate $(\nabla)$.

Fig. 2. Distribution (\%) of isotope incorporated from sodium $\left[{ }^{14} \mathrm{C}\right]$ bicarbonate by propionategrown Micrococcus denitrificans into malate $(O)$, succinate $(O)$, glutamate $(\triangle)$ and aspartate $(\triangle)$.

\section{Effect of arsenite on propionate utilization}

A further test of this route of propionate utilization was provided by measurement of the incorporation of sodium $\left[{ }^{4} \mathrm{C}\right]$ bicarbonate by washed suspensions of propionategrown Micrococcus denitrificans, which were oxidizing either L-malate or propionate in the presence of this isotopically labelled material and sodium arsenite. Manometric experiments showed arsenite to be a powerful inhibitor of propionate oxidation: in its presence, only $10 \mu$ moles of oxygen were absorbed by organisms incubated in air with $10 \mu$ moles of propionate; and over $8 \mu$ moles of pyruvate were found to have accumulated after the uptake of oxygen ceased. This relationship

$$
\mathrm{CH}_{3} \cdot \mathrm{CH}_{2} \cdot \mathrm{CO}_{2} \mathrm{H}+\mathrm{O}_{2} \rightarrow \mathrm{CH}_{3} \cdot \mathrm{CO} \cdot \mathrm{CO}_{2} \mathrm{H}+\mathrm{H}_{2} \mathrm{O}
$$

cannot by itself reveal the route whereby propionate is converted into pyruvate. However, it would be expected that, if the utilization of propionate involved its prior carboxylation to succinate and the succinate were to give rise to pyruvate via fumarate, malate and oxaloacetate, the pyruvate thus formed and accumulated would be labelled if sodium $\left[{ }^{14} \mathrm{C}\right.$ [bicarbonate were also included in the medium. It would further be expected that routes for propionate utilization not involving an obligatory fixation 
of ${ }^{14} \mathrm{CO}_{2}$ would, if operating, yield pyruvate containing little or no isotope; moreover, the oxidation of substances other than propionate-such as L-malate-would, under these conditions, give rise to pyruvate labelled only to the extent that isotopic exchange reactions occurred. As shown in Table 1, these expectations were fulfilled. Whereas the oxaloacetate and pyruvate formed from L-malate, in the presence of arsenite and sodium $\left[{ }^{14} \mathrm{C}\right]$ bicarbonate, contained a total of only 3000 counts $/ 100 \mathrm{sec}$., these $\alpha$-oxoacids derived from propionate under similar conditions contained over 140 times as much ${ }^{14} \mathrm{C}$. Consequently, the formation of pyruvate from propionate, but not that from L-malate, must have involved a major fixation of carbon dioxide.

Table. 1. Incorporation of ${ }^{14} \mathrm{C}$ by Micrococcus denitrificans when oxidizing unlabelled L-malate or propionate, in the presence of sodium $\left[{ }^{14} \mathrm{C}\right]$ bicarbonate and sodium arsenite

Each of two stoppered flasks contained $1 \mathrm{ml}$. of $0.1 \mathrm{M}$-tris buffer (pH 8);0.4 ml. of $0.01 \mathrm{M}$-sodium arsenite; $1 \mathrm{ml}$. of propionate-grown $M$. denitrificans (equiv: $17 \mathrm{mg}$. dry wt.); $0.9 \mathrm{ml}$. water and $0.5 \mathrm{ml}$. of sodium $\left[{ }^{14} \mathrm{C}\right]$ bicarbonate $(100 \mu \mathrm{c})$ solution. One of the flasks also received $0.2 \mathrm{ml}$. of $0.1 \mathrm{M}$-sodium L-malate; the other received $0.2 \mathrm{ml}$. of $0.1 \mathrm{M}$-sodium propionate. The flasks were shaken at $30^{\circ}$ for $2 \mathrm{~h}$, after which time $1 \mathrm{ml}$. of the contents was pipetted into $3 \mathrm{ml}$. of hot ethanol, and $1 \mathrm{ml}$. into $2 \mathrm{ml}$. of $0.1 \% 2,4$-dinitrophenylhydrazine hydrochloride in $2 \mathrm{~N}-\mathrm{HCl}$. The radioactivity of the ethanol-soluble materials was assayed directly on aluminium planchets, whereas the 2,4-dinitrophenylhydrazones of $\alpha$-oxoacids were separated and identified by paper chromatography (El Hawary \& Thompson, 1953) and their radioactivity assayed directly on the paper.

\begin{tabular}{lccc} 
& \multicolumn{3}{c}{$\begin{array}{c}\text { Total }{ }^{14} \mathrm{C}\left(\text { counts } / 100 \mathrm{sec} . \times 10^{-3}\right) \\
\text { incorporated into: }\end{array}$} \\
\cline { 2 - 4 } Substrate & $\begin{array}{c}\text { Ethanol-soluble } \\
\text { fraction }\end{array}$ & Oxaloacetate & Pyruvate \\
L-Malate & 3.4 & 1.2 & 1.8 \\
Propionate & 522 & 4.6 & 422
\end{tabular}

Incorporation of ${ }^{14} \mathrm{C}$ from sodium $\left[{ }^{14} \mathrm{C}\right]$ carbonate by cell-free extracts

The condensation of labelled carbon dioxide and unlabelled propionate, implied to occur by the experiments with intact organisms, was readily demonstrable when cellfree extracts of propionate-grown Micrococcus denitrificans were used. A major fixation of isotope from sodium $\left[{ }^{14} \mathrm{C}\right]$ carbonate into acid-stable materials was observed when such extracts were incubated with either propionate + coenzyme A + ATP, or with propionyl-coenzyme A + ATP. As shown in Table 2, $1 \mu$ mole of propionylcoenzyme A was apparently a more effective acceptor for the isotopic carbon dioxide than were $5 \mu$ moles of propionate. The reaction did not proceed when ATP or propionate were omitted and, with the unpurified cell extract used, omission of coenzyme A caused only a slight decrease in the quantities of labelled carbon dioxide fixed.

When the labelled products obtained from propionyl-coenzyme A and sodium $\left[{ }^{14} \mathrm{C}\right]$ carbonate were analysed directly by two-dimensional paper chromatography and autoradiography, two major radioactive materials and three minor ones were found. The major labelled products were succinate and a diffuse material running in the position usually occupied by coenzyme $A$ esters; the minor products were malate, fumarate and aspartate. Alkaline hydrolysis of the sample before chromatography, by the procedure indicated in outline in the footnote of Table 2, caused the total dis- 
appearance of the diffuse labelled material, the intensification of the succinate spot and the appearance of a different but compact spot of labelled material: this latter compound was identified, by co-chromatography in several solvents (Kornberg, 1958) with the authentic compound, as a salt of methylmalonic acid. It is thus likely that the diffuse labelled material was a mixture of the coenzyme A esters of succinic and methylmalonic acids. Hence, it is also likely that the fixation of carbon dioxide to propionate proceeds predominantly via the enzymic sequence first elucidated for mammalian systems (for details of this sequence, see review by Kaziro \& Ochoa, 1964).

\section{Table 2. Incorporation of isotope from sodium $\left[{ }^{14} \mathrm{C}\right]$ carbonate by cell-free extracts of propionate-grown Micrococcus denitrificans}

The complete system contained, in a final volume of $1.0 \mathrm{ml} ., 100 \mu$ moles of tris buffer (pH 8.5); $10 \mu$ moles of magnesium chloride; $5 \mu$ moles of ATP; ultrasonic extract of propionategrown $M$. denitrificans (containing $2 \mathrm{mg}$. protein); $10 \mu$ moles of sodium $\left[{ }^{14} \mathrm{C}\right.$ carbonate (containing $20 \mu \mathrm{c}$ of isotope); $5 \mu$ moles of propionate or $1 \mu$ mole of propionyl-coenzyme A; $0.05 \mu$ mole of coenzyme A; water. The mixtures were incubated at $30^{\circ}$ for $30 \mathrm{~min}$. and then mixed with $3 \mathrm{ml}$. of hot ethanol; of the resulting mixture, $0.1 \mathrm{ml}$. was spotted on to an aluminium planchet. The material was evaporated to dryness, irrigated with $10 \%(\mathrm{w} / \mathrm{v})$ acetic acid and re-dried to constant radioactivity.

Contents of incubation mixture
Complete: propionate
ATP omitted
Propionate omitted
Coenzyme A omitted
Complete: propionyl-coenzyme A

Total ${ }^{14} \mathrm{C}$ incorporated (counts/ 100 sec. $\left.\times 10^{-3}\right)$

127
$4 \cdot 8$
$6 \cdot 2$
96
$323^{*}$

*After incubation of the ethanolic solution with $2 \mathrm{~N}$-potassium hydroxide for $30 \mathrm{~min}$. at $23^{\circ}$ followed by neutralization with perchloric acid and analysis by two-dimensional paper-chromatography and autoradiography (Kornberg, 1958) of the supernatant solution, the isotopically labelled products formed from propionyl coenzyme $A$ and sodium $\left[{ }^{14} \mathrm{C}\right]$ bicarbonate were:

$\begin{array}{lc}\text { Labelled material } & \begin{array}{c}\text { Percentage of } \\ \text { total }\end{array} \\ \text { Succinate } & 63 \\ \text { Methyl malonate } & 12 \\ \text { Malate } & 15 \\ \text { Fumarate } & 4 \\ \text { Aspartate } & 6\end{array}$

\section{DISCUSSION}

The enzymic mechanism whereby propionate is utilized by mammalian tissues has been shown to involve the fixation of carbon dioxide to yield, ultimately, succinate, via isomers of methylmalonyl-coenzyme A and succinyl-coenzyme A (for review, see Kaziro \& Ochoa, 1964). Although this sequence of reactions has been reported to occur also in Rhodospirillum rubrum (Gibson \& Knight, 1961; Knight, 1962) and a Propionibacter species (Stadtman, Overath, Eggerer \& Lynen, 1960), many other species of bacteria do not appear to use this route for the utilization of propionate. Rather do such organisms convert propionyl coenzyme A initially to acrylyl-coenzyme $\mathrm{A}$, and thence either to acetyl-coenzyme $\mathrm{A}$ and carbon dioxide (via $\beta$-hydroxypropionylcoenzyme A and either malonic semialdehyde or malonyl-coenzyme A; Vagelos, 
1960; Callely \& Lloyd, 1964), or form pyruvate from acrylyl-coenzyme A, possibly via lactyl-coenzyme A (Vagelos, Earl \& Stadtman, 1959). It has also been suggested that propionyl-coenzyme A may be utilized through an initial condensation with glyoxylate to form $\alpha$-hydroxyglutarate, which is alleged to be cleaved to acetate and pyruvate (Reeves \& Ajl, 1963).

The results obtained with Micrococcus denitrificans show that propionate utilization by this organism does not proceed via any of the variety of routes peculiar to plants and to other micro-organisms, but occurs through reactions closely similar to those found in mammalian tissues. In addition to the direct evidence to this effect obtained with intact micrococci and extracts derived therefrom, it is also apparent that the operation of other pathways is contra-indicated. Thus, the high degree of labelling in pyruvate, formed from unlabelled propionate and labelled carbon dioxide, argues against any major formation of pyruvate from propionate via acrylyl-coenzyme A; the virtual absence of isocitrate lyase from extracts of propionate-grown $M$. denitrificans also rules out the formation of the glyoxylate necessary for the initiation of the $\alpha$-hydroxyglutarate pathway proposed by Reeves \& Ajl (1963).

The support of the Science Research Council, through Grant B/SR/652 is gratefully acknowledged.

\section{REFERENCES}

Callely, A. G. \& Lloyd, D. (1964). The metabolism of propionate in the colourless alga, Prototheca zopfii. Biochem. J. 92, 338.

El Hawary, M. F. S. \& Thompson, R. H. S. (1953). Separation and estimation of blood keto acids by paper chromatography. Biochem. $J .53,340$.

FrENCH, I. W., KORNBERG, H. L. \& MoRrIS, J. G. (1964). Alternative pathways of acetate utilization by Micrococcus denitrificans. Biochem. J. 92, 55 P.

Gibson, J. \& KNIGHT, M. (1961). Carboxylation of propionyl-coenzyme A by extracts of Rhodospirillum rubrum, Biochem. J. 78, 8P.

KAzIRo, Y. \& OCHOA, S. (1964). The metabolism of propionic acid. Adv. Enzymol. $26,283$.

KNIGHT, M. (1962). The photometabolism of propionate by Rhodospirillum rubrum. Biochem. J. 84, 170.

KoRnBerg, H. L. (1958). The metabolism of $\mathrm{C}_{2}$-compounds in micro-organisms. 1. The incorporation of $\left[2-{ }^{14} \mathrm{C}\right]$ acetate by Pseudomonas fluorescens, and by a Corynebacterium, grown on ammonium acetate. Biochem. J. 68, 535.

KORNBERG, H. L. \& MORRIS, J. G. (1965). The utilization of glycollate by Micrococcus denitrificans: the $\beta$-hydroxyaspartate pathway. Biochem. J. 95, 577.

ReEves, H. C. \& AJ, S. J. (1963). Enzymatic formation of lactate and acetate from $\alpha$-hydroxyglutarate. Biochem. biophys. Res. Commun. 12, 132.

Stadtman, E. R. (1957), Preparation and assay of acyl coenzyme A and other thiol esters; use of hydroxylamine. Meth. Enzymol. 3, 931.

Stadtman, E. R., Overath, P., EgGerer, H. \& Lynen, F. (1960). The role of biotin and vitamin $\mathrm{B}_{12}$ coenzyme in propionate metabolism. Biochem. biophys. Res. Commun. $2,1$.

Vagelos, P. R. (1960). Propionic acid metabolism. IV. Synthesis of malonyl coenzyme A. J. biol. Chem. 235, 346.

Vagelos, P. R., Earl, J. M. \& Stadtman, E. R. (1959). Propionic acid metabolism. II. Enzymatic synthesis of lactyl pantetheine. J. biol. Chem. 234, 765 . 